\title{
Salmonellosis Outbreaks in the United States Due to Fresh Produce: Sources and Potential Intervention Measures
}

\author{
Irene B. Hanning, ${ }^{1}$ J.D. Nutt, ${ }^{2, *}$ and Steven C. Ricke ${ }^{1,3}$
}

\begin{abstract}
Foodborne Salmonella spp. is a leading cause of foodborne illness in the United States each year. Traditionally, most cases of salmonellosis were thought to originate from meat and poultry products. However, an increasing number of salmonellosis outbreaks are occurring as a result of contaminated produce. Several produce items specifically have been identified in outbreaks, and the ability of Salmonella to attach or internalize into vegetables and fruits may be factors that make these produce items more likely to be sources of Salmonella. In addition, environmental factors including contaminated water sources used to irrigate and wash produce crops have been implicated in a large number of outbreaks. Salmonella is carried by both domesticated and wild animals and can contaminate freshwater by direct or indirect contact. In some cases, direct contact of produce or seeds with contaminated manure or animal wastes can lead to contaminated crops. This review examines outbreaks of Salmonella due to contaminated produce, the potential sources of Salmonella, and possible control measures to prevent contamination of produce.
\end{abstract}

\section{Introduction}

$\mathbf{R}$ ECENT ADVANCES IN PROCESSING TECHNIQUES, preservation, and packaging have enabled the fresh fruit and vegetable industry to consistently supply consumers with a wide array of products year round in much greater quantities. Produce consumption in the United States has risen in recent years due to the increase of public health interests and diet trends. The sales of salad mixes alone increased from $\$ 167.5$ million in 1991 to \$507 million in 1994 (E. Garrett, International Fresh Cut Produce Association, Arlington, VA, personal communication, 1996). The increased consumption nearly doubled production values of lettuce from $\$ 1.3$ billion dollars in 1999 to $\$ 2$ billion in 2004 (USDA-ERS, 2005). It is generally perceived that consumption of raw fresh produce products is safe and that most foodborne disease outbreaks are caused by foods primarily of animal origin (Sivapalasingam et al., 2004). However, the potential for foodborne pathogen contamination is apparent in many aspects of vegetable production practices. Accordingly, fresh fruit and vegetables have been implicated in a myriad of foodborne outbreaks and as sources of foodborne pathogens (Doan and Davidson, 2000; Sewell and Farber, 2001; Castillo and Rodríguez-García, 2004; Mandrell and Brandal, 2004; Sivapalasingam et al., 2004).

Fresh fruits and vegetables may be contaminated with either spoilage or pathogenic microorganisms through cultivation practices, handling, and processing (Tournas, 2005). Because the addition of preservation methods is often absent in vegetable processing, there is a potentially greater risk for microbial populations to contaminate and deteriorate the product (Thomas and O'Beirne, 2000). Recent documented foodborne disease outbreaks associated with fresh produce have been on the rise. Bean and Griffin (1990) reported that fruits and vegetables were the cause of $2 \%$ of the foodborne disease outbreaks in the United States between 1973 and 1987. By the 1990s, this had risen to $6 \%$ of all reported foodborne outbreaks with over 16,000 cases of illness identified from fresh produce and produce dishes in the United States (Sivapalasingam et al., 2004; Mandrell and Brandal, 2004). The most recent data indicate that $13 \%$ of outbreaks in the United

\footnotetext{
${ }^{1}$ Center for Food Safety-IFSE and Department of Food Science, University of Arkansas, Fayetteville, Arkansas.

${ }^{2}$ Poultry Science Department, Texas A\&M University, College Station, Texas.

${ }^{3}$ Poultry Science Department, University of Arkansas, Fayetteville, Arkansas.

*Current address: Yum! Brands Inc., Dallas, Texas.
} 
States may be attributed to produce contaminated with foodborne pathogens (Doyle and Erickson, 2007).

As demand for vegetables and other crops continues to rise, the need for freshwater sources to provide irrigation also increases. This can be especially problematic for freshwater sources that come in contact with regions where there are large confined animal operations or large numbers of grazing animals. In the western United States animal grazing is substantial enough to impact water quality (Larsen et al., 1994). In addition, the application of animal wastes to agricultural soils can increase levels of foodborne pathogens originating from the manure of animal carriers (Crane et al., 1983; Edwards and Daniels, 1992; Solomon et al., 2002; Hutchison et al., 2004). In areas that are more densely populated or are closer to large municipalities, raw sewage waste also can be a source of human pathogens (Ait Melloul et al., 2001).

The globalization and importation of the food supply has resulted in unique food safety challenges. The cooperation of international agencies, formation of worldwide regulations, and enhanced surveillance systems are indispensable for a safe food supply (Kaferstein, 2003). The United States Department of Agriculture-Economic Research Service (USDAERS, 2008) estimates $13 \%$ of vegetables and $32 \%$ of fruits and nuts consumed in the United States in 2007 were imported, up from $16.4 \%$ total fruits and vegetables in 1996 . The burden of inspecting these imported food items is placed on regulatory agencies that only inspect about $1 \%$ of imported food (Buzby et al., 2008). Because greater volumes of fresh fruits and vegetables are being imported along with greater volumes being consumed, it is expected that the number of foodborne illnesses due to produce will increase (Harris et al., 2003).

Salmonella is a leading cause of foodborne illness in the United States (CDC, 2008a). The USDA-ERS estimated 1.4 million cases of salmonellosis occurred in 2007 costing 2.5 billion dollars in terms of lost productivity and medical costs (USDA-ERS, 2007). Salmonella has been shown to survive or grow in a wide variety of produce. This review will focus on produce that has been implicated in foodborne outbreaks in the United States. Although outbreaks can also be attributed to multiple sources including food preparers and the food preparation environment, contamination of produce early in the production chain such as the field and processing environment will be the focus of this review. The environmental aquatic sources of Salmonella contamination of produce also are examined. Finally, control measures for limiting Salmonella contamination in produce are discussed.

\section{Produce Outbreaks Due to Salmonella}

Salmonellae are commonly found in the gastrointestinal tract of numerous animals such as birds, reptiles, farm animals, and humans. Most cases of salmonellosis were previously thought to be attributed to consuming contaminated poultry and poultry products (Tauxe et al., 1997). However, an increasing number of produce-associated foodborne outbreaks in the United States associated with bacterial contamination are primarily from Salmonella (Tauxe et al., 1997; Harris et al., 2003). In fact, from 2002 to 2003, 31 produceassociated outbreaks of Salmonella were reported while only 29 outbreaks were poultry related (CDC, 2008a). A wide variety of produce has been shown to be a source of Salmonella outbreaks including tomatoes, sprouts, watermelon, cantaloupe, lettuce, and mangoes (Tauxe et al., 1997). Outbreak investigations of Salmonella infection implicated watermelons as early as 1950 (Harris et al., 2003).

Produce-linked outbreaks of Salmonella are summarized in Table 1. Typically in larger outbreaks, the source of Salmonella that contaminated the produce is eventually identified. However, trace-back investigations can be hindered due to the complexity of the food supply. Information such as brand name, date of purchase, Universal Product Code (UPC) code, and lot numbers are important for pinpointing a contaminated food item and may not be available. Furthermore, trace-back investigations rely on consumers that have become ill for information and may only provide limited information because 1) only a limited number of cases are available; 2) people that are interviewed typically have a limited recall about the foods that were eaten; and/or 3) the food source of the outbreak is no longer available for testing. As demonstrated by the recent 2008 outbreak of salmonellosis due to Serrano peppers, an investigation can be hindered if the right questions are not asked; in the 2008 outbreak, initial questionnaires by investigating agencies did not specifically ask if peppers were recently eaten (CDC, 2008b). Furthermore, it is estimated that only 1 case of salmonellosis out of 38 may be reported to the public health authorities and this also limits outbreak investigations (Voetsch et al., 2004). Outbreaks due to specific produce items are discussed in the following sections. In most cases, details of the larger outbreaks were available and are given.

\section{Melon}

Melons have been associated with multiple salmonellosis outbreaks. Between 1989 and 1991, two consecutive outbreaks that sickened more than 400 people occurred due to contaminated cantaloupe originating from Mexico and Texas (CDC, 1991). Several past outbreaks have also been associated with watermelon but comparatively fewer cases were reported (Gayler et al., 1955; CDC, 1979). If the outside of the melon is contaminated, cutting the melon can transfer Salmonella to the edible portions (Gayler et al., 1955; Ukuku and Sapers, 2007). Since melons are rich in sugars and nutrients and have a nearly neutral pH (Gagliardi et al., 2003), it is not surprising that when contaminated melon pieces are not stored properly (i.e., room temperature) Salmonella populations can increase (Ukuku and Sapers, 2007).

The contamination of melons can be from multiple sources including contaminated manure, irrigation water, fertilizers, wildlife, wash water, processing equipment, and/or packaging (Kaneko et al., 1999). However, a survey of farm and processing facilities found that a majority of Salmonella contamination resulted from the rind being inoculated during immersion in contaminated wash water in post-harvest facilities (Gagliardi et al., 2003). Water in the wash tank or coolers that becomes contaminated can inoculate large numbers of melons subsequently washed in the same water. Cantaloupes, in particular, are difficult to clean once they are inoculated because the surface of the melon has lenticles (netting) that provide areas for attachment and protection from sanitizers (Lester, 1988; Gagliardi et al., 2003). Vigorous scrubbing with multiple detergents and disinfectants is necessary to remove contamination and may not remove all of the pathogens (Barak et al., 2003; Parnella et al., 2005). 
Therefore, preventing the initial contamination of melons in the wash tank is considered a critical control point.

The voluntary Melon Quality Control Program was initiated by the produce industry in 1992 because of the increasing number of Salmonella-contaminated melon products (unpublished discussion, Melon Quality Program meeting, Dallas, TX, October 14, 1991; Mohle-Boetani et al., 1999). Recommendations coming out of this program include the use of hyperchlorinated water in all processing steps of fruit and vegetable production to help reduce bacterial contamination (Tauxe et al., 1997). However, this program is voluntary for U.S. producers and imported melons may not follow these guidelines. As a result, outbreaks of salmonellosis from imported melons continued after the program implementation as demonstrated by the 2008 outbreak due to cantaloupe imported from Honduras (FDA, 2008a).

Careful monitoring of chlorine levels in wash water is critical because chlorine levels can be rapidly neutralized by organic materials washed from the melons. In addition, chlorine may produce off-flavors and undesirable appearance of foods, and may be harmful to the environment. Alternatives to chlorination have been studied. Bacteriophage treatment was reported to effectively reduce Salmonella populations on cut melon by $3.5 \log _{10}$ (Leverentz et al., 2001). However, like antibiotics, Salmonella can become resistant to bacteriophages, which eventually renders this treatment ineffective (Santander and Robeson, 2007). Hydrogen peroxide application has also been demonstrated to be effective, but only if treated within 24 hours of contamination (Ukuku and Fett, 2002). Similarly, commercial sanitizers were only effective if used within 1 hour of inoculating melons (Ukuku and Sapers, 2007).

The need for effective treatments that can disinfect contaminated melons remains. The genetic basis for Salmonella attachment to plants has been discovered and this information could be used to develop effective treatments. It has been demonstrated that Salmonella regulates production of cellulose using the $b c s A$ gene and the $\mathrm{O}$-antigen capsule gene yihO in order to attach to and colonize plants (Barak et al., 2007). A key regulator of the $\mathrm{O}$-antigen capsule and cellulose production is the positive regulator AgfD (Zogaj et al., 2001; Barak et al., 2005). In addition to regulation of these genes, AgfD is also suggested to be a key regulator for survival of Salmonella outside the host (Barak et al., 2007). Thin aggregative fimbrae may also be used for attachment and genes required for expression of fimbrae include $r p o S$ and $a g f D$ (Romling et al., 2005). Importantly, these genes are also necessary for virulence expression during human infection (Barak et al., 2005).

Using this information, potential treatment options could be explored by monitoring Salmonella genes after exposure to treatments to determine any effect on attachment and virulence. For example, organic acids have been explored as antimicrobial treatments and the organic acids butyrate, propionate, and acetate all have biocidal effects against Salmonella (Ricke, 2003; Van Immerseel et al., 2006). Butyrate and propionate decreased expression of hilA (virulence gene regulator), invF (cell invasion factor), and sipC (cell invasion protein), but acetate led to an increase of hilA and invF (Durant et al., 2000; Lawhon et al., 2002). Therefore, acetate may not be a good choice as an antimicrobial due to increases in virulence expression. Furthermore, any Salmonella surviving exposure to an organic acid may be more likely to survive further acid treatment due to the induction of an acid tolerance response and produce cross-protection to other antimicrobials (Kwon and Ricke, 1998; Kwon et al., 2000; Ricke, 2003).

\section{Sprouts}

In 1999, the U.S. Food and Drug Administration (FDA) issued guidelines for sprout seed decontamination and testing of sprout irrigation waters (FDA, 1999). In three outbreaks of Salmonella Enteritidis from 2000 to 2001, it was determined that the contamination was a result of these guidelines not being followed (Mohle-Boetani et al., 2009). Specifically, the seeds were being treated with $11,000 \mathrm{ppm}$ or less sodium hypochlorite rather than the FDA-recommended level of 20,000 ppm (Winthrop et al., 2003; Mohle-Boetani et al., 2009). Additionally, sprout irrigation water at the producer's farm tested positive for Salmonella. A survey of California sprout growers confirmed that most alfalfa sprout growers were achieving the 20,000 ppm disinfection guidelines and if followed, disinfection was achieved (Thomas et al., 2003). However, the same survey found that the mung bean sprouts sampled were not achieving the disinfection guidelines and thus mung bean sprouts may represent a larger risk. It was noted in this survey that seeds and calcium hypochlorite were not measured prior to mixing with water which may partially explain why treatment was not fully effective.

In the outbreaks of Salmonella Enteritidis due to contaminated mung sprouts, growers and private laboratories, which noted positive results, did not inform public health officials (Mohle-Boetani et al., 2009). Furthermore, the grower continued to use seeds from a contaminated lot. These two points perpetuated the outbreak which could have been interrupted with help from public health officials. However, it is not clearly recommended that growers report positive results to public health officials, which represents a serious gap in food safety.

From 1995 to 2003, no fewer than 10 outbreaks of salmonellosis occurred due to contaminated sprouts. Alfalfa sprouts were the source of two large outbreaks in 1995 and 1996, in which more than 700 people were made ill and one death was reported. Mung sprouts were also a source of Salmonella that resulted in 45 reported illnesses in 2000 (Mohle-Boetani et al., 2009). One potential source of contamination to seeds may be contact with birds or rodents during storage or shipping (Mahon et al., 1997). In addition, some seeds may be set or scored in fields upon which animals directly graze and these seeds can become contaminated from animal feces (Brooks et al., 2001). This is the scenario of an outbreak in September of 2008 in which 13 illnesses in Washington and Oregon of Salmonella Typhimurium were directly linked to consuming alfalfa sprouts (FDA, 2008b).

Because Salmonella can survive for months on seeds (Beuchat and Scouten, 2002) and has the ability to grow during the sprouting process, even a low level of seed contamination can be considered a risk. The growth of Salmonella during the sprouting process has been well documented (Jacquette et al., 1996; Gandhi et al., 2001). In fact, under certain sprouting conditions, Salmonella can grow as much as 4 $\log _{10}$ units in 48 hours (Fu et al., 2008). However, technological advances in equipment used and in practices during cultivation have been implemented to reduce growth during 


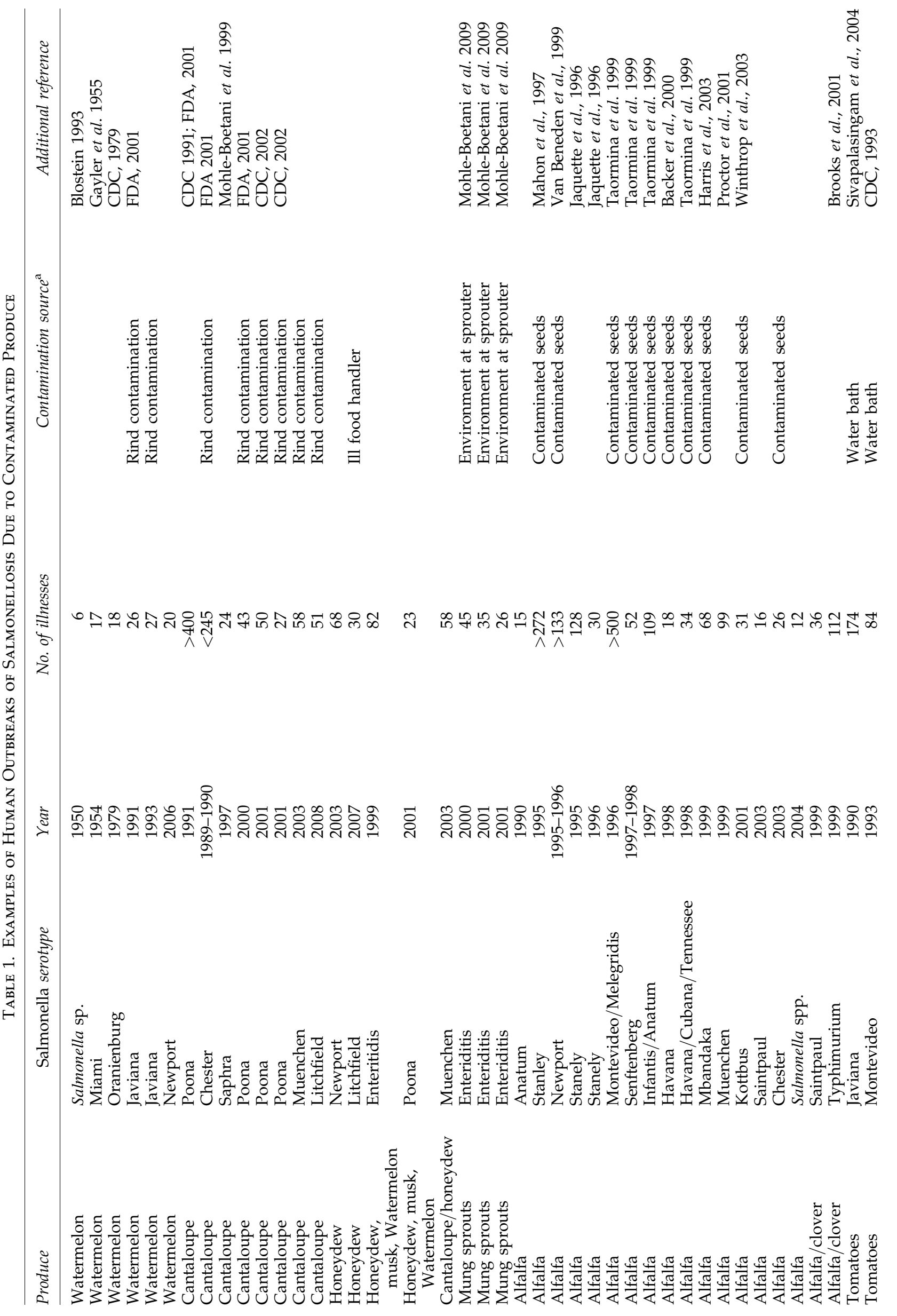


¿े

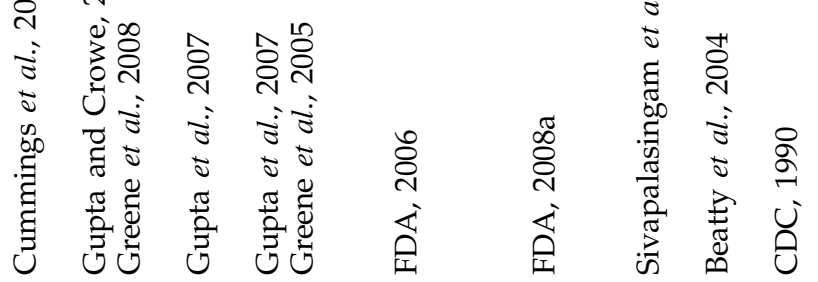

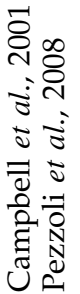
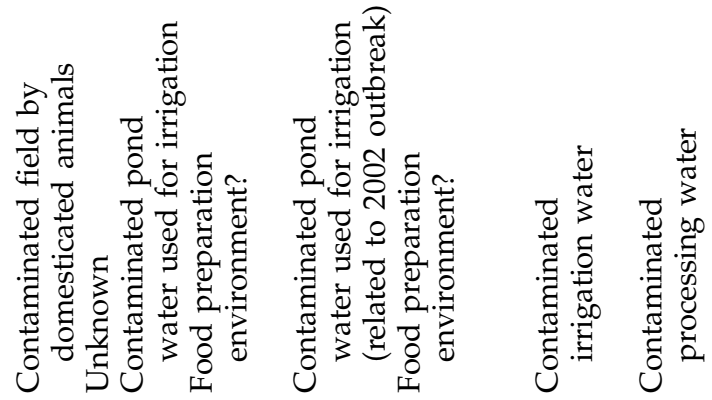

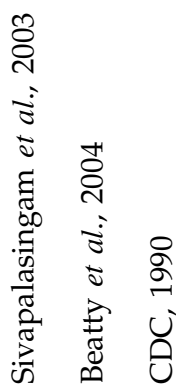

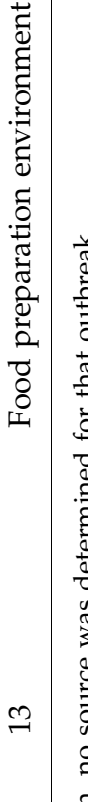

$\infty$ 군

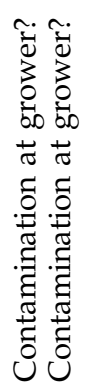

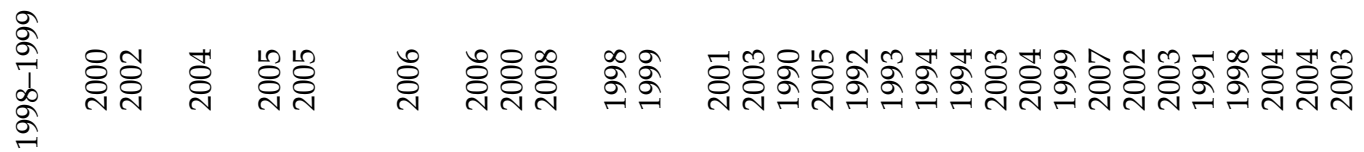

$\infty$

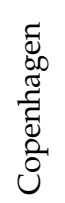

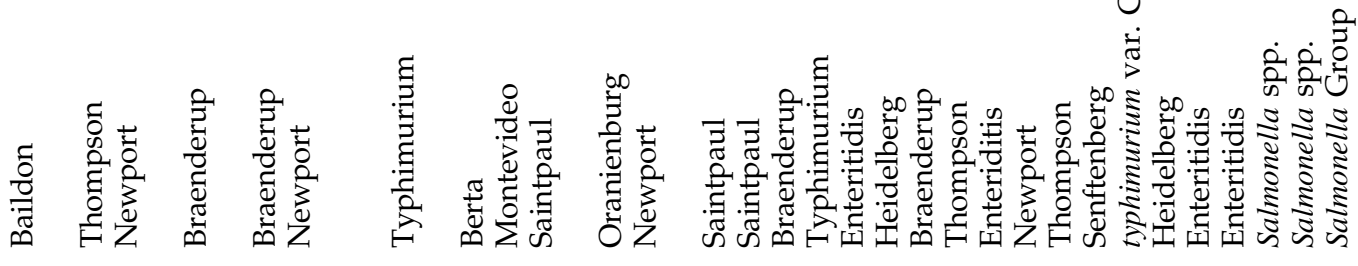

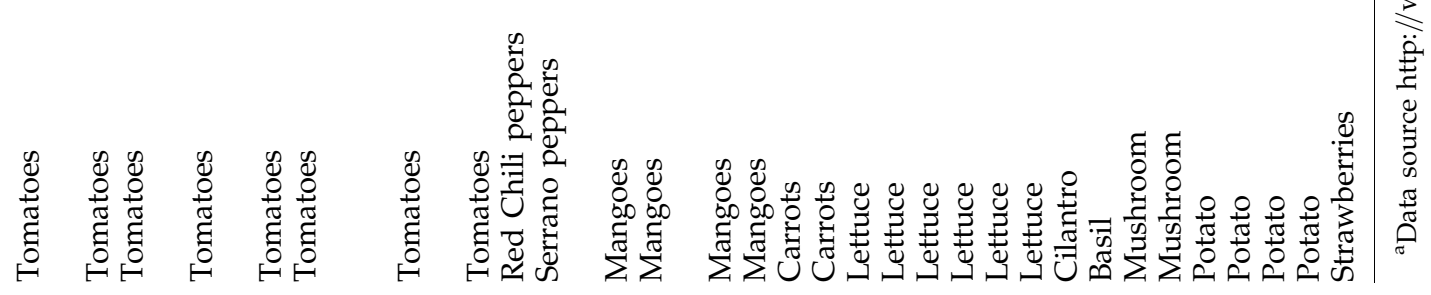


sprouting. Among these improvements are using a rotary drum sprouting process and employing frequent irrigation with unrestricted drainage, which has been shown to aid in washing away any pathogen contamination (Fu et al., 2008). In addition, cool water used for irrigation and cool air blowing over the sprouts has also been demonstrated to reduce the rate of pathogen growth.

Even with these improvements, the risk of contamination to products still exists which warrants a need for effective post-harvest treatments. For example, Gandhi and Matthews (2003) demonstrated that combined treatment of seeds with 20,000 ppm calcium hypochlorite followed by 100 ppm chlorine or calcinated calcium during germination and sprout growth did not eliminate Salmonella from alfalfa seeds and sprouts. Low doses of irradiation ( 1 to $2 \mathrm{kGy}$ ) were effective at eliminating Salmonella and did not adversely affect sensory or nutritional properties of the sprouts (Saroj et al., 2007), but public perception of irradiated food remains suspicious at best (O'Bryan et al., 2008). Each treatment option has some drawbacks, therefore, before any commercial application can be pursued, additional treatments need to be evaluated to determine the optimal treatment to render sprouts safe.

\section{Tomatoes}

Salmonella outbreaks due to contaminated produce are usually widely dispersed, which suggests that contamination is occurring early in production, such as in the field or in a processing plant. Contamination of tomatoes early in production may occur by a mechanism described by Zhuang et al. (1995). The researchers demonstrated that if dilated plant cells on the surface of a warm tomato are exposed to cold water contaminated with Salmonella, the cells of the tomato will rapidly contract and take in the Salmonella through openings such as the stem scar. It has also been demonstrated that Salmonella inoculated onto the surface of the tomato can attach to the exterior of the tomato and populations can increase with time, depending on the environmental conditions (Iturriaga et al., 2007). Shi et al. (2007) reported that many serovars of Salmonella can colonize and survive on tomatoes, but that growth was serovar dependent. Serovars Enteritidis, Typhimurium, and Dublin (group D serovars more commonly associated with poultry) were less adapted to grow and persist than Hadar, Montevideo, or Newport (group C serovars). The ability of only some serovars to grow in tomatoes may be a reason why only a few serovars of Salmonella are linked to outbreaks. The $\mathrm{pH}$ of tomatoes is fairly acidic and ranges from 3.4 to 4.8 depending on the ripeness of the tomato (Wolf et al., 1979). However, even at this pH, Zhuang et al. (1995) demonstrated that Salmonella Montevideo populations in chopped tomatoes can increase by 1.5 and $2.5 \log$ units when stored for 22 hours at temperatures of $20^{\circ} \mathrm{C}$ and $30^{\circ} \mathrm{C}$, respectively.

Investigations of Salmonella outbreaks due to contaminated tomatoes have pinpointed sources including contaminated irrigation water and contaminated wash water (Table 1). One particular outbreak in 2005 was eventually linked to an outbreak that occurred 3 years earlier that was thought to have affected as many as 2500 people (Greene et al., 2008). Through use of pulsed-field gel electrophoresis, isolates from these two outbreaks were shown to be genotypically identical to each other and to Salmonella isolated from pond water that was being used for irrigation purposes. No source of Salmonella to the pond water was isolated, but investigators speculated that wild birds, reptiles, or amphibians were a likely source.

Once contaminated, tomatoes may be difficult to clean because the efficacy of chlorine to remove Salmonella on tomatoes depends on the location of Salmonella on the tomato. Salmonella on stem scars and cracks in the skin survive better than Salmonella on the smooth skin (Cummings et al., 2001). Furthermore, the ability of Salmonella and other foodborne pathogens to internalize into tomatoes and other produce creates a significant challenge of eliminating the bacteria from these foods. Sanitizing treatments are generally ineffective against internalized pathogens because they are physically protected from the chemicals. Like chlorine, treatments such as electrolyzed water or ozonated water were shown to eliminate Salmonella from the surfaces of the tomato (Chaidez et al., 2007; Park et al., 2008) but are ineffective at reaching any internalized Salmonella. Currently, irradiation is the only effective treatment for eliminating Salmonella that is internalized in tomatoes or any other produce because of its ability to penetrate tissues of produce to eliminate internalized pathogens (Saroj et al., 2007). Furthermore, Gram-negative bacteria are very susceptible to even low doses (O'Bryan et al., 2008). However, treatment with irradiation can produce off flavors, colors, and odors and destroy some nutrients (Fan and Sokorai, 2008). As previously discussed, a lack of public approval of irradiation hinders the employment of this method for treating foods (O'Bryan et al., 2008).

\section{Mangoes}

Contaminated mangoes have been responsible for several outbreaks of salmonellosis in the United States. Like tomatoes, mangoes can internalize Salmonella to the fruit portion via the stem scar (Bordini et al., 2007). However, unlike tomatoes, mangoes have a nearly neutral $\mathrm{pH}$ and high sugar content that is conducive to bacterial growth. Bordini et al. (2007) showed that any internalized Salmonella survives during cold storage $\left(8^{\circ} \mathrm{C}\right)$ and replicates at room temperature $\left(22^{\circ} \mathrm{C}\right)$.

Imported mangoes typically receive a hot water immersion treatment $\left(46.1^{\circ} \mathrm{C}\right.$ for 70 to 90 minutes) followed by a cold water treatment $\left(21.1^{\circ} \mathrm{C}\right.$ for 30 minutes) to control any fly larvae on the fruit (Schirra et al., 2000). If the cold rinse water is contaminated with bacteria, bacteria can contaminate the fruit on the outer surfaces and the inner edible portion. The internalization mechanism of Salmonella into the mangoes can be explained by air spaces present in the warm fruit contracting when immersed in the cold water thus drawing the cold water into the fruit (Merker et al., 1999). Salmonella internalized into mango was thought to be the source of a salmonellosis outbreak in 1999. In this outbreak, the contamination was traced back to contaminated wash water. The tanks were unenclosed and toads, wild birds, and bird feces were found around the tanks, which were the most likely sources of Salmonella (Sivapalasingam et al., 2003).

Like tomatoes, no effective treatment exists to eliminate Salmonella from mangoes once the bacteria are internalized. This emphasizes the need for effective treatments of wash water in tanks to remove any Salmonella contaminating the outside of the fruit and to kill any Salmonella that might be introduced into the wash water. In fact, inadequately chlorinated wash water is thought to be a large contributing factor 
to the 1999 and 2001 outbreaks of Salmonella in mangoes (Beatty et al., 2004). Research supports the effectiveness of chlorine treatment of the wash water. Soto et al. (2007) demonstrated that either chlorine or copper ion treatment of wash water was effective at preventing internalization of Salmonella in mangoes. Until research leads to treatments that can consistently eliminate internalized Salmonella, effective treatment and control of Salmonella in the wash water will be crucial to preventing salmonellosis due to contaminated produce.

\section{Serrano peppers}

In April of 2008, an outbreak of Salmonella serotype Saintpaul began (FDA, 2008c). There were 57 cases of salmonellosis in Texas and New Mexico with 17 hospitalizations and 30 more cases being investigated in seven other states. Preliminary investigations suggested Roma, plum, or round tomatoes were the source of Salmonella. By early June, 145 cases were reported and 23 people were hospitalized across 16 states. Tomatoes remained the suspected cause at this point, but the Salmonella causing the outbreak had not been isolated from tomatoes or growers' fields. In mid-July, after a lengthy investigation the FDA determined that tomatoes were not the source of the outbreak. However, by this time 1220 people were sickened in 42 states, the District of Columbia, and Canada. The FDA shifted the warning from consuming raw tomatoes to jalapeno and Serrano peppers. The source of the outbreak was finally identified and reported on July 30, 2008, to be contaminated irrigation water used at a farm in Mexico to water crops of jalapeno and Serrano peppers.

The outbreak due to contaminated Serrano peppers was the largest outbreak of salmonellosis due to fresh produce in the United States. Besides losses incurred due to medical costs and loss of productivity, this particular outbreak included additional costs that tomato growers incurred. Tomato sales plummeted due to the FDA-issued warning against the consumption of tomatoes. Florida growers alone estimated losses of 100 million dollars and were requesting disaster relief funds from the government. The United Fresh Produce Association claims federal agencies caused more than 300 million dollars in losses nationwide. Since tomatoes had been the source of multiple outbreaks in the past and no outbreaks have been recorded from Serrano peppers, tomatoes seemed like the most likely source. However, this outbreak demonstrated that Salmonella can potentially contaminate any type of produce.

\section{Minor outbreaks and vegetables as indirect sources}

Less extensive outbreaks due to mushrooms, carrots, lettuce, and other produce have been reported. There remains very little information concerning the relatively less prominent outbreaks due to reasons previously discussed in Produce Outbreaks Due To Salmonella. In addition, since these vegetables are usually consumed together with other vegetables in salads, it is difficult to distinguish the single vegetable source of the pathogen. Herbs, in particularly cilantro and basil, have been implicated in outbreaks. In 1999, cilantro was identified as a probable source of salmonellosis, but the point of contamination was never firmly identified (Campbell et al., 1999). Contaminated basil caused an international outbreak that sickened 19 people in the United Kingdom (Pezzoli et al., 2008). There were also 11 cases in the United States with the same pulse-type as the Salmonella Thompson isolated from the basil but only three of the patients confirmed consuming basil.

In the case of potatoes, potato salads containing mayonnaise are typically thought to be the primary source of infection since mayonnaise contains eggs and eggs are a leading source of Salmonella (CDC, 2008a). Therefore, some prepared potato salads that are improperly stored have led to foodborne salmonellosis. If eggs containing Salmonella are used and acidic vinegar is not added, the Salmonella remains viable in the mayonnaise (Xiong et al., 1999; Morgan et al., 2007). Commercially prepared mayonnaise has a water activity, $\mathrm{pH}$, and salt content that creates a very hostile environment for Salmonella. In fact, research has shown that the addition of commercially produced mayonnaise actually inhibits the growth of Salmonella in some foods (Doyle, 2005).

Besides the produce linked to outbreaks, Salmonella has been identified from a number of produce items purchased at retail. Salmonella has been isolated from oranges, chilis, cabbage, artichokes, cauliflower, celery, eggplant, spinach, and zucchini (Harris et al., 2003). This may be due to differences in processing of the produce item post-harvest or the fact that some of the produce items are consumed after cooking. In addition, there may be some intrinsic factors associated with these items that prevents Salmonella from growing in the product or modifies virulence properties of Salmonella. It has been suggested that the food matrix influences the virulence of pathogens because differences in stresses associated with food matrices can have varying affects on bacterial growth physiology and gene expression (Buchanan and Bagi, 2000; Nutt et al., 2003a). Comparing these produce items with produce that has been implicated in outbreaks may provide valuable information that could be used to develop control strategies for Salmonella in produce.

The outbreaks from tomatoes, peppers, and melons that affected hundreds of people across multiple states demonstrate that clean irrigation water is critical to preventing contamination of crops. Contamination of irrigation water can be difficult to trace and sources such as domestic animal manure can pollute irrigation water (Uhlich et al., 2008). If not properly addressed, these sources of contamination can persist and cause continuous outbreaks such as the tomato outbreaks of 2002 and 2005, which were both linked to the same water source but occurred over a 3-year period (Greene et al., 2008). The importance of environmental sources of Salmonella and the potential route of contamination to produce are discussed in the following sections.

\section{Environmental Sources of Vegetable Salmonella Contamination}

\section{Contamination from the environment}

Contamination of fresh produce can occur virtually anywhere throughout the production process. Preharvest sources of contamination are likely to be present before the fruits or vegetables are even removed from their natural environments. Many spore-forming bacteria such as Clostridium botulinum, C. perfringens, and enterotoxigenic Bacillus cereus are found in the soil and may be naturally present on some fruits and vegetables (Beuchat and Ryu, 1997). Other types of bacteria or viruses present on fresh produce may be due to direct contact with fecal material or exposure to untreated wastewater used for irrigation. The use of raw animal manure 
as fertilizer can increase the presence of microorganisms on fruits and vegetables as well (Crane et al., 1983; Edwards and Daniels, 1992; Solomon et al., 2002; Hutchison et al., 2004). Another source of preharvest contamination that is often overlooked is contact with wild or domestic animals. For example, wild birds are known to potentially harbor bacterial foodborne pathogens including Campylobacter and Salmonella (Luechtefeld et al., 1980; Keener et al., 2004; Saleha, 2004). Contact with fecal material from these animals can potentially result in the contamination of vegetable crops.

Specific agricultural practices such as the use of animal manure as opposed to chemical fertilizers may be a factor in introducing these foodborne pathogens to fresh produce (Tauxe et al., 1997). Also, the use of contaminated irrigation water is a potential vehicle for transferring Salmonella to the surfaces of fresh fruits and vegetables (Steele and Odumeru, 2004). Given the incidence of Salmonella as a foodborne pathogen in general and its distribution in a variety of environments, Salmonella species causing foodborne disease are of particular concern as produce contaminants.

\section{Foodborne Salmonella in animal sources}

A majority of Salmonella infections are zoonotic and the type of animal reservoir is a vital factor in understanding the epidemiological pattern of the disease. While poultry is considered the most prevalent and important source of salmonellae (CDC, 2008a), other animals have been shown to harbor this bacterial species as well. Reptiles are known to carry a variety of Salmonella serovars including S. enterica (Geue and Löschner, 2002). In a report issued by the Centers for Disease Control and Prevention (CDC), it was reported that there were over 50,000 cases of reptile-associated salmonellosis in 1996 (CDC, 1999). Cattle have also been documented to be a source of Salmonella as well as Escherichia coli (Himathongkham et al., 1999). Cattle infected with Salmonella can excrete cells through milk or feces in the absence of any type of clinical symptoms (Losinger et al., 1995). Cattle recovering from a clinical salmonellosis infection may shed the organism typically from 2 to 12 weeks (Galland et al., 2000).

The use of animal manure to fertilize soil is both economically and environmentally beneficial in maintaining soil fertility and quality. However, animal manure used to fertilize grazing grasses of pastures can introduce pathogens that can eventually colonize the gastrointestinal tracts of other food animals and animals from which manure is produced (Holley et al., 2008). Manures used to fertilize crops that contain pathogens can eventually contaminate produce products. There is some competition with soil organisms as well as adverse conditions that can lead to a reduction of pathogens; however, Salmonella has been shown to survive in soil samples for 231 days (Islam et al., 2004). Furthermore, Islam et al. (2004) suggested that pathogen movement through the soil is likely and they could reach aquifers or surface waters. If these waters are used for irrigation, crop contamination may occur.

An additional factor to consider is the ability of pathogens to become endophytes. Contaminated irrigation water and subsequent internalization of E. coli O157:H7 into spinach resulted in a large outbreak causing 204 people to become ill (Anonymous, 2006). The simple recycling of animal wastes can lead to large outbreaks and highly complex epidemiological investigations. Therefore, it is critical to control and eliminate pathogens from manure regardless of where the manure is applied.

\section{Presence of Salmonella in water}

The microbiological quality of irrigation water, regardless of the source, is crucial in maintaining safe food products. Non-wastewater sources that are not normally considered contaminated with waste or fecal material could play a large role in the presence of Salmonella and other microorganisms on fresh produce. Major rivers have been used as irrigation sources for many agricultural settings (Assadian et al., 1999; Garcia et al., 2001). The annual bacterial loads of Salmonella in these rivers and coastal areas are essential for assessing potential risk (Baudart et al., 2000). Salmonella appear to possess the mechanisms to retain viability and successfully survive in these river environments as well. In samples of river water, Salmonella cells were shown to be viable even after 31 days of exposure as determined by reculturing and obtaining plate counts (Santo Domingo et al., 2000). Furthermore, Salmonella cells exposed to and surviving stresses associated with freshwater laboratory microcosms have been demonstrated to increase the expression of a key virulence gene regulator (Nutt et al., 2003b).

Not only do Salmonella cells survive in river-water samples but this may be one of the larger reservoirs harboring viable bacteria. Baudart et al. (2000) reported that Salmonella Typhimurium was dominant in river water and marine and freshwater sediments. They concluded that the presence of this species in the marine sediments near the river discharge supported the ability of Salmonella to survive long-term in a natural environment. In a study by Polo et al. (1998), environmental water samples were collected and plated on media selective for Salmonella cells. River-water samples yielded the highest proportion of Salmonella cells compared to other sampled water sources from beaches and freshwater reservoirs. This raises a major concern given that currently many rivers are used extensively as irrigation sources for fruits and vegetables.

\section{Strategies for Limiting Salmonella Contamination of Produce}

The produce industry faces unique challenges for eliminating pathogen contamination when compared to other types of foods due to three specific factors related to produce: 1) produce is typically consumed without cooking; 2) produce is usually not packaged; and 3) the ability of pathogens to internalize into produce exists. Due to these factors, addressing prevention of contamination at all stages of production is necessary. However, since bacteria are ubiquitous throughout nature, it is unrealistic to assume that pathogen-free produce can always be achieved.

Contamination intervention strategies such as Hazard Analysis and Critical Control Point (HACCP) that were first implemented for meat products are being designed for produce production. The application of HACCP to minimally processed crops has been reviewed (Hurst, 2006; Leifert et al., 2008). HACCP aims to identify, monitor, and control potential points in processing that might introduce hazards to the finished product. A determination of the critical control points in any production system is a complex procedure that varies with each product and the process being used (Sperber, 1992). 
The USDA guide to minimize microbial food safety hazards for fresh fruits and vegetables suggests proactive monitoring of potential critical control points such as microbial testing of agricultural water (USDA, FDA/CFSAN, 1998). However, even with the proper plan and systems in place, it may still be possible for some microbial contamination to occur and it is at that point that corrective actions need to be taken. Corrective actions can involve two activities: 1) determining and fixing the point in the production chain at which contamination was introduced; and 2) determining what to do with the product.

Potentially contaminated products will need to be evaluated to determine if a microbiological risk exists. After which it can be determined if treatments will render the product safe or if the product will have to be discarded. Treatment options to eliminate bacteria from produce are being explored. Even packaging is being designed with specific applications for produce. These challenges producers face and options for addressing problems are discussed in the next sections.

\section{Elimination of pathogens}

Treatment of produce poses a particular challenge because consumers demand a fresh and minimally processed product. Furthermore, not all treatments may be equally effective at eliminating different types of bacteria. For these reasons, multiple hurdle or sequential intervention strategies may ultimately be the best option for produce growers and processors. This type of strategy first described by Leistner (1985) employs the use of several treatments in a sequential order to eliminate bacteria. Using this approach, the first treatment can sublethally injure bacteria to the point they are not allowed to recover before the application of a subsequent treatment. Since sublethally injured bacteria are more susceptible to treatments than unstressed cells (Ray, 1986), sequential application of treatments is more effective at killing bacteria than any single treatment. A sequential treatment plan was shown to be effective for decontaminating raw beef (Delmore et al., 1998). A combination of pre-eviseration washing, an acetic acid rinse, and a final wash followed by a second acetic acid resulted in a reduction of coliform counts of nearly 2 logs while washing or acetic acid rinse alone resulted in 0.4 and 1.1 log reductions, respectively. Similarly, Kang et al. (2001) reported a combination of hot water rinse, followed by hot air treatment and sequential rinses with lactic acid were more effective at reducing microbial contamination on beef trim than any single treatment.

Using multiple treatments may allow producers to reduce the severity of treatments, which could result in a higher quality product. This approach could be particularly useful for irradiation of foods since high levels of irradiation can produce off flavors and colors, but lower levels may not be fully effective at eliminating bacteria (O'Bryan et al., 2008). For example, a low dose of irradiation alone did not destroy clostridia spores but was sufficient to sensitize spores to further heat treatment (Patterson, 2001). Similarly, the combination of treating carrots with plant oils and packaging in modified atmosphere lowered the minimum doses of irradiation necessary to eliminate Listeria from 0.36 to $0.17 \mathrm{kGy}$ (Caillet et al., 2006).

Even if a completely pathogen-free product is achieved after processing, a large problem to the produce industry is the lack of packaging that can help prevent re-contamination of products following any sanitizing steps. Produce can be exposed to multiple contamination routes following processing during shipping and display in retail markets. Packaging is typically not used for produce but some new technologies are being developed.

\section{Prevention of pathogen recontamination and growth by packaging}

Most produce items are sold without packaging, therefore the possibility of contamination is present after any postharvest treatment. Akins et al. (2008) reported that cantaloupe taken from the wash tank exhibited lower microbial counts than cantaloupe taken after conveyor belts in the packaging area of the processing plant. This suggested that the conveyor belts may have contributed to recontamination of the cantaloupe. The risk of contamination at the retail level also exists simply due to the fact that most produce is not packaged and can be subsequently contaminated by handling. EspinozaMedina et al. (2006) reported that $16.7 \%$ of workers handling produce were polymerase chain reaction positive for Salmonella.

The use of packaging for cut produce not only reduces this risk of contamination but also allows implementing the means to extend shelf-life. The produce industry has employed methods such as modified atmospheric packaging (MAP) to help suppress microbial growth in their products and to extend shelf life. MAP is a commonly used packaging system to suppress growth of microorganisms where produce is packaged in a low level of $\mathrm{O}_{2}$ that is replaced with $\mathrm{N}_{2}$ or $\mathrm{CO}_{2}$ (typically $50 \% \mathrm{O}_{2}, 30 \% \mathrm{~N}_{2}$, and $20 \% \mathrm{CO}_{2}$ ). This atmosphere can result in a lower $\mathrm{pH}$, which may inhibit the growth of bacteria (Daniels et al., 1985). Evidence has also shown that elevated levels of $\mathrm{CO}_{2}$ in produce packaging extends the lag phase of bacteria and can help slow its growth (Zagory, 1999). The nature and abundance of the gasses used in MAP affect certain types of organisms in different ways. Lower levels of $\mathrm{O}_{2}$ allow for the growth of microaerophilic organisms such as lactic acid bacteria while elevated $\mathrm{CO}_{2}$ levels favor Grampositive as opposed to Gram-negative bacteria (Brackett, 1987).

However, the capability of these MAP systems may not always yield products that are safe for consumption and are sometimes ineffective in reducing microbial growth. AbdulRaouf et al. (1993) determined that the use of MAP was not effective in decreasing the survival capabilities of E. coli O157:H7 on cucumber or shredded lettuce samples. Synergistic treatment approaches have been suggested such as the use of MAP in combination with a disinfectant-containing wash and may be more effective. Jin and Lee (2007) found that MAP alone had no effect on reducing the levels of Salmonella on mung sprouts, but the combined treatments of chlorine dioxide wash and MAP reduced Salmonella by $3.0 \mathrm{log}$ CFU/g and maintained a reduced level for 7 days.

Edible films have been explored for applications as packaging of produce. The edible film can create a modified atmosphere around the fruit or vegetable that can aid in extending shelf-life (Navarro-Tarazaga et al., 2008). Edible coatings also offer a moisture barrier that can prevent weight loss of the produce (Baldwin, 1997). In addition, coatings can be impregnated with antimicrobials that could improve food safety quality (Vargas et al., 2008). However, problems of 
functionality and durability are associated with the use of edible films for produce. Furthermore, any antimicrobials would only be effective against the microorganisms located on the produce surface. Further engineering of edible films for produce application is currently being developed (Vargas et al., 2008).

\section{Conclusions}

A considerable challenge remains to ensure safe produce due to a lack of packaging and the possibility of the produce becoming recontaminated after any post-harvest treatment. Ultimately, a multiple hurdle approach may be the most effective strategy for eliminating Salmonella from produce. The ability of pathogens to become internalized into fruit or endophytes within plant tissues also poses a considerable challenge for producers. The internalization of pathogens in produce has sparked extensive research efforts towards developing methods to remove pathogens from the tissues. As the molecular basis of the internalization and interactions with plants is currently being investigated becomes better understood this may provide valuable information to develop more effective intervention strategies (Heaton and Jones, 2008).

Wastewater and freshwater contamination by foodborne pathogens can contribute to the eventual contamination of fruits and vegetables irrigated with water sources that come in contact with these sources. The effect of aquatic environments on pathogen survival and incidence may have a subsequent impact on the amount of contamination. The overall focus of future research needs to be directed at environmental points of bacterial contamination in vegetable production including animal and water sources because of the ubiquitous nature of their ecology. Foodborne salmonellae are an ideal group of bacteria to understand how to differentiate the relative importance of these dissemination pathways and optimal methods for control. This should provide considerable insight because Salmonella have been extensively studied and are sufficiently well known genetically for molecular methods to be readily applicable.

\section{Acknowledgements}

This review and JDN were supported by the Texas Higher Education Coordinating Board's Advanced Technology Program (\#000517-0361-1999) and Hatch grant H8311 administered by the Texas Agricultural Experiment Station. Authors IH and SCR are supported by USDA-NRI grant \# 2007-3520118380.

\section{Disclosure Statement}

No competing financial interests exist.

\section{References}

Abdul-Raouf UM, Beuchat LR, and Ammar MS. Survival and growth of E. coli O157:H7 on salad vegetables. Appl Environ Microbiol 1993;59:1999-2006.

Ait Melloul A, Hassani L, and Rafouk L. Salmonella contamination of vegetables irrigated with untreated wastewater. World J Microb Biot 2001;17:207-209.

Akins D, Harrison M, and Hurst W. Washing practices on the microflora on Georgia-grown cantaloupe. J Food Prot 2008; 71:46-51.
Anonymous. Ongoing multistate outbreak of Escherichia coli serotype O157:H7 infections associated with consumption of fresh spinach. Morb Mortal Wkly Rep 2006;55:1-2.

Assadian NW, Fenn LB, Flores-Ortiz MA, et al. Spatial variability of solutes in a pecan orchard surface-irrigated with untreated effluents in the upper Rio Grande River basin. Agric Water Manag 1999;42:143-156.

Backer HD, Mohle-Boetani JC, Werner SB, et al. 2000. High incidence of extra-intestinal infections in a Salmonella Havana outbreak associated with alfalfa sprouts. Public Health Rep 2000;115:339-45.

Baldwin EA, Nisperos MO, Hagenmaier RD, et al. Use of lipids in coatings for food products. Food Technol 1997;51:663.

Barak J, Chue B, and Mills D. Recovery of surface bacteria from and surface sanitization of cantaloupes. J Food Prot 2003; 66:1805-1810.

Barak J, Gorski L, Naraghi-Arani P, et al. Salmonella enterica virulence genes are required for bacterial attachment to plant tissue. Appl Environ Microbiol 2005;71:5685-5691.

Barak JD, Jahn C, Gibson D, et al. The role of cellulose and $\mathrm{O}$-antigen capsule in the colonization of plants by Salmonella enterica. Mol Plant Microbe Interact 2007;20:1083-1090.

Baudart J, Grabulos J, Barusseau JP, et al. Salmonella spp. and fecal coliform loads in coastal waters from a point vs. nonpoint source of pollution. J Environ Qual 2000;29:241-250.

Bean NH and Griffin PH. Foodborne disease outbreaks in the United States, 1973-1987: pathogens, vehicles, and trends. J Food Prot 1990;53:804-817.

Beatty ME, LaPorte TN, Phan Q, et al. A multistate outbreak of Salmonella enterica serotype Saintpaul infections linked to mango consumption: a recurrent theme. Clin Infect Dis 2004;38:1337-1338.

Beuchat LR and Ryu JH. Produce handling and processing practices. Emerg Infect Dis 1997;3:459-465.

Beuchat LR and Scouten AJ. Combined effects of water activity, temperature and chemical treatments on the survival of Salmonella and Escherichia coli O157:H7 on alfalfa seeds. J Appl Microbiol 2002;92:382-395.

Blostein J. An outbreak of Salmonella Javiana associated with consumption of watermelon. J Environ Health 1993;56:2931.

Bordini M, Ristori C, Jakabi M, et al. Incidence, internalization and behavior of Salmonella in mangoes, var. Tommy Atkins. Food Control 2007;18:1002-1007.

Brackett RE. Microbial consequences of minimally processed fruits and vegetables. J Food Qual 1987;10:195-206.

Brooks J, Samantha Y, Rowe PS, Heltzel D, Hunter S, Slutsker L, Hoekstra R, and Luby S. Salmonella Typhimurium infections transmitted by chlorine-pretreated clover sprout seeds. Amer J Epidem 2001;154:1020-1028.

Buchanan R and Bagi L. Microbial competition: effect of culture conditions on the suppression of Listeria monocytogenes Scott A by Carnobacterium piscicola. J Food Prot 2000;60:254-261.

Buzby JC, Unnevehr LJ, and Roberts D. Food Safety and Imports: an analysis of FDA food-related import refusal reports. Bulletin no. 39. September 2008. Available at http://www .ers.usda.gov/Publications/EIB39/EIB39.pdf. Washington, DC: United States Department of Agriculture-Economic Research Service, 2008.

Caillet S, Millette M, Turgis M, et al. Influence of antimicrobial compounds and modified atmosphere packaging on radiation sensitivity of Listeria monocytogenes present in readyto-use carrots (Daucus carota). J Food Prot 2006;69:221-227. 
Campbell J, Mohle-Boetani J, Reporter R, et al. An outbreak of Salmonella serotype Thompson associated with fresh cilantro. J Infect Dis 2001;183:984-987.

Castillo A and Rodríguez-García MO. Bacterial hazards in fresh and fresh-cut produce: sources and control. In: Pre-harvest and Post-Harvest Food Safety: Contemporary Issues and Future Directions. Beier RC, Pillai SD, Phillips TD, et al. (eds). Ames, IA: Blackwell Publishing Professional, 2004, pp. 43-57.

[CDC] Centers for Disease Control and Prevention. Salmonella oranienburg gastroenteritis associated with consumption of precut watermelons Illinois. Morb Mortal Wkly Rep 1979;28: 522-523.

[CDC] Centers for Disease Control and Prevention. 1990 Foodborne Disease Outbreak Line Listing. Available at: http://www.cdc.gov/foodborneoutbreaks/us_outb/fbo1990/ fbofinal1990.pdf. Atlanta, GA: CDC, 1990.

[CDC] Centers for Disease Control and Prevention. Multistate outbreak of Salmonella poona infections-United States and Canada. Morb Mortal Wkly Rep 1991;40:549-552.

[CDC] Centers for Disease Control and Prevention. Multi-state outbreak of Salmonella serotype Montivideo infections. Publication EPI-AID 93-97. Atlanta, GA: CDC, 1993.

[CDC] Centers for Disease Control and Prevention. Reptileassociated salmonellosis-selected states. Morb Mortal Wkly Rep 1999;48:1008-1013.

[CDC] Centers for Disease Control and Prevention. Multistate outbreaks of Salmonella serotype Poona infections associated with eating cantaloupe from Mexico-United States and Canada, 2000-2002. Morb Mortal Wkly Rep 2002;51:1044-1047.

[CDC] Centers for Disease Control and Prevention. Annual listing of foodborne disease outbreaks. Available at http://www.cdc.gov/foodborneoutbreaks/outbreak_data.htm. Atlanta, GA; CDC, 2008a.

[CDC] Centers for Disease Control and Prevention. Outbreak of Salmonella serotype Saintpaul infections associated with multiple raw produce items-United States, 2008. Morb Mortal Wkly Rep 2008b;57:929-934.

Chaidez C, Lopez J, Vidales J, et al. Efficacy of chlorinated and ozonated water in reducing Salmonella typhimurium attached to tomato surfaces. Int J Environ Health Res 2007;17:311-318.

Crane SR, Moore JA, Grismer ME, et al. Bacterial pollution from agricultural sources: a review. Trans ASAE (Am Soc Agric Eng) 1983;26:858-872.

Cummings K, Barrett E, Mohle-Boetani J, et al. A multi-state outbreak of Salmonella enterica serotype Baildon associated with domestic raw tomatoes. Emerg Infect Dis 2001;7:1046-1048.

Daniels JA, Krishnamurthi R, and Rizvi SSH. A review of the effect of carbon dioxide on microbial growth and food quality. J Food Prot 1985;48:532-537.

Delmore L, Sofos J, Schmidt G, et al. Decontamination of inoculated beef with sequential spraying treatments. J Food Sci 1998:63:890-900.

Doan $\mathrm{CH}$, Davidson MP. Microbiology of potatoes and potato products: a review. J Food Prot 2000;63:668-683.

Doyle M. UGA scientists find mayonnaise makes meat salads safer. Available at http://www.ugacfs.org/hottopics/mayonnaise .html. Accessed August 13, 2008. Griffin, GA: University of Georgia, 2005.

Doyle M and Erickson M. Summer meeting 2007-the problems with fresh produce: an overview. J Appl Microbiol 2007;105: 317-330.

Durant JA, Corrier DE, and Ricke SC. Short-chain volatile fatty modulate the expression of the hilA and invF genes of Salmonella Typhimurium. J Food Prot 2000;63:573-578.
Edwards DR and Daniels TC. Environmental impacts of on-farm poultry waste disposal-a review. Bioresource Tech 1992; 41:9-33.

Espinoza-Medina IE, Rodriguez-Leyva FJ, Vargas-Arispuro I, et al. PCR identification of Salmonella: potential contamination sources from production and postharvest handling of cantaloupes. J Food Prot 2006;69:1422-1425.

Fan X and Sokorai KJ. 2008. Retention of quality and nutritional value of 13 fresh-cut vegetables treated with low-dose radiation. J Food Sci 2008;73:S367-72.

[FDA] U.S. Food and Drug Administration. Guidance for industry: reducing microbial food safety hazards for sprouted seeds and guidance for industry: sampling and microbial testing of spent irrigation water during sprout production. Fed Reg 1999;64:57893-57902.

[FDA] U.S. Food and Drug Administration. Program information manual. Retail food safety. Produce safety at retail: safe handling practices for melons. Available at http://www .cfsan.fda.gov/ ear/ret-mln.html. Rockville, MD: FDA, 2001.

[FDA] U.S. Food and Drug Administration. FDA notifies consumers that tomatoes in restaurants linked to Salmonella Typhimurium outbreak current information suggests outbreak is not ongoing. Available at http://www.fda.gov/bbs/ topics/NEWS/2006/NEW01504.html. Rockville, MD: FDA, 2006.

[FDA] U.S. Food and Drug Administration. 2008a. FDA Warns of Salmonella risk with cantaloupes from Agropecuaria Montelibano: the agency detains products from the Honduran manufacturer. Available at http://www.fda.gov/bbs/ topics/NEWS/2008/NEW01808.html. Rockville, MD: FDA, 2008a.

[FDA] U.S. Food and Drug Administration. Sprouters Northwest, Inc. recalls alfalfa sprout products because of possible health concern. Available at http://www.fda.gov/oc/ po/firmrecalls/sprouters09_08.html. Rockville, MD; FDA, 2008b.

[FDA] U.S. Food and Drug Administration. Salmonella Saintpaul outbreak. Updated August 28, 2008. Available at: http:// www.fda.gov/oc/opacom/hottopics/tomatoes.html. Rockville, MD: FDA, 2008c.

Fu T, Reineke K, Chirtel S, et al. Factors influencing the growth of Salmonella during sprouting of naturally contaminated alfalfa seeds. J Food Prot 2008;71:888-896.

Gagliardi J, Millner P, Lester G, et al. On-farm and postharvest processing sources of bacterial contamination to melon rinds. J Food Prot 2003;66:82-87.

Galland JC, House JK, Hyatt DR, et al. Prevalence of Salmonella in beef feeder steers as determined by bacterial culture and ELISA serology. Vet Microbiol 2000;76:143-151.

Gandhi M, Golding S, Yaron S, et al. Use of green fluorescent protein expressing Salmonella Stanley to investigate survival, spatial location, and control on alfalfa sprouts. J Food Prot 2001;64:1891-1898.

Gandhi M and Matthews KR. Efficacy of chlorine and calcinated calcium treatment of alfalfa seeds and sprouts to eliminate Salmonella. Int J Food Microbiol 2003;87:301-306.

Garcia SS, Ake C, Clement B, et al. Initial results of environmental monitoring in the Texas Rio Grande Valley. Environ Int 2001;26:465-474.

Gayler GE, MacCready RA, Reardon JP, et al. An outbreak of salmonellosis traced to watermelon. Public Health Rep 1955;70:311-313.

Geue L and Löschner U. Salmonella enterica in reptiles of German and Austrian origin. Vet Microbiol 2002;84:79-91. 
Greene SK, Daly ER, Talbot EA, et al. Recurrent multistate outbreak of Salmonella Newport associated with tomatoes from contaminated fields, 2005. Emerg Infect Dis 2008;136:157165.

Gupta A and Crowe C. Multi-state outbreak of Salmonella Thompson, November-December, 2000. Atlanta, GA: Centers for Disease Control and Prevention, 20 February 2001.

Gupta A, Nalluswami K, Snider C, et al. Outbreak of Salmonella Braenderup infections associated with Roma tomatoes, northeastern United States, 2004: a useful method for subtyping exposures in field investigations. Epidem Infec 2007;135:1165-1173.

Harris LJ, Farber JN, Beuchat LR, et al. Outbreaks associated with fresh produce: incidence, growth, and survival of pathogens in fresh and fresh-cut produce. Comp Rev Food Sci Food Safety 2003;2:78-141.

Heaton JC and Jones K. Microbial contamination of fruit and vegetables and the behaviour of enteropathogens in the phyllosphere: a review. J Appl Microbiol 2008;104:613-626.

Himathongkham S, Bahari S, Riemann $\mathrm{H}$, et al. Survival of Escherichia coli O157:H7 and Salmonella typhimurium in cow manure and cow manure slurry. Fed Eur Microbiol Soc Microbiol Lett 1999;178:251-257.

Holley R, Walkty J, Blank G, et al. Examination of Salmonella and Escherichia coli translocation from hog manure to forage, soil, and cattle grazed on the hog manure-treated pasture. J Environ Qual 2008;37:2083-92.

Hurst W. HACCP: A process control approach for fruit and vegetable safety. In: Microbiology of fruits and vegetables. Sapers G, Gorny J, Yousef A (eds). Boca Raton, FL: CRC Press, 2006, pp. 339-364.

Hutchison M, Walters L, Avery SM, et al. Levels of zoonotic agents in British livestock manures. Lett Appl Microbiol 2004;39:207-214.

Islam M, Morgan J, Doyle MP, et al. Persistence of Salmonella enterica serovar Typhimurium on lettuce and parsley and in soils on which they were grown in fields treated with contaminated manure composts or irrigation water. Foodborne Pathog Dis 2004;1:27-35.

Iturriaga M, Tamplin M, and Escartin E. Colonization of tomatoes by Salmonella Montevideo is affected by relative humidity and storage temperature. J Food Prot 2007;70:30-34.

Jaquette CB, Beuchat LR, and Mahon BE. Efficacy of chlorine and heat treatment in killing Salmonella Stanley inoculated onto alfalfa seeds and growth and survival of the pathogen during sprouting and storage. Appl Environ Microbiol 1996;62:2212-2215.

Jin $\mathrm{HH}$ and Lee SY. Combined effect of aqueous chlorine dioxide and modified atmosphere packaging on inhibiting Salmonella Typhimurium and Listeria monocytogenes in mungbean sprouts. J Food Sci 2007;72:M441-445.

Kaferstein FK. Actions to reverse the upward curve of foodborne illness. Food Control 2003;14:101-109.

Kaneko KI, Hayashidani H, Takahashi K, et al. Bacterial contamination in the environment of food factories processing ready-to-eat fresh vegetables. J Food Prot 1999;62:800-804.

Kang DH, Koohmaraie M, Dorsa WJ, et al. Development of a multiple-step process for the microbial decontamination of beef trim. J Food Prot 2001;64:63-71.

Keener KM, Bashor MP, Curtis PA, et al. Comprehensive review of Campylobacter and poultry processing. Comp Rev Food Sci Food Saf 2004;3:105-116.

Kwon YM, Park SY, Birkhold SG, et al. Induction of resistance of Salmonella Typhimurium to environmental stresses by exposure to short-chain fatty acids. J Food Sci 2000;65:10371040.

Kwon YM and Ricke SC. Induction of acid resistance of Salmonella Typhimurium by exposure to short-chain fatty acids. Appl Environ Microbiol 1998;64:3458-3463.

Larsen RE, Miner JR, Buckhouse JC, et al. Water-quality benefits of having cattle manure deposited away from streams. Bioresour Technol 1994;48:113-118.

Lawhon SD, Maurer R, Suyemoto M, et al. Intestinal short-chain fatty acids alter Salmonella Typhimurium invasion gene expression and virulence through BarA/SirA. Mol Microbiol 2002;46:1451-1464.

Leifert C, Ball K, Volakakis N, et al. Control of enteric pathogens in ready-to-eat vegetable crops in organic and 'low input' production systems: a HACCP-based approach. J Appl Microbiol 2008;105:931-950.

Leistner, L. Hurdle technology applied to meat products of the shelf-stable product and intermediate moisture food types. In: Properties of water and food. Samantos D, Multon J (eds). Dordrecht: Martinus Nijhoff Publishers, 1985, pp. 309329.

Lester, G. Comparisons of "honey dew" and netted muskmelon fruit tissues in relation to storage life. Hortscience 1988;23:180182.

Leverentz B, Conway WS, Alavidze Z, et al. Examination of bacteriophage as a biocontrol method for Salmonella on freshcut fruit: a model study. J Food Prot 2001;64:1116-1121.

Losinger WC, Wells SJ, Garber LP, et al. Management factors related to Salmonella shedding by dairy heifers. J Dairy Sci 1995;78:2464-2472.

Luechtefeld NAW, Blaser MJ, Reller LB, et al. Isolation of Campylobacter fetus subsp. jejuni from migratory waterfowl. J Clin Microbiol 1980;12:406-408.

Mahon B, Ponka A, Hall W, et al. An international outbreak of Salmonella infections caused by alfalfa sprouts grown from contaminated seeds. J Infect Dis 1997;175:876-882.

Mandrell RE and Brandal MT. Campylobacter species and fresh produce: outbreaks, incidence, and biology. In: Pre-harvest and Post-Harvest Food Safety: Contemporary Issues and Future Directions. Beier RC, Pillai SD, Phillips TD, et al. (eds). Ames, IA: Blackwell Publishing Professional, 2004, pp. 59-72.

Merker R, Edelson-Mamel S, Davis V, et al. Preliminary experiments on the effects of temperature differences on dye uptake by oranges and grapefruits. Available at http://vm.cfsan .fda.gov/ comm/juicexp.html. Accessed August 13, 2008. Rockville, MD: U.S. Food and Drug Administration, Center for Food Safety and Applied Nutrition, 1999.

Mohle-Boetani J, Farrar J, Bradley P, et al. Salmonella infections associated with mung bean sprouts 2000-2002: Epidemiological and environmental investigations. Epidemiol Infect 2009;137:357-366.

Mohle-Boetani J, Reporter R, Werner S, et al. An outbreak of Salmonella serogroup Saphra due to cantaloupes from Mexico. J Infect Dis 1999;180:1361-1364.

Morgan O, Milne L, Kumar S, et al. Outbreak of Salmonella Enteritidis phage type 13a: case-control investigation in Hertsmere, United Kingdom. Euro Surveill 2007;12:E9-10.

Navarro-Tarazaga M, Sothornvit R, and Perez-Gago M. Effect of plasticizer type and amount on hydroxypropyl methylcellulosebeeswax edible film properties and postharvest quality of coated plums. J Agric Food Chem 2008;56:9502-9509.

Nutt JD, Li X, Woodward CL, et al. Growth kinetics response of a Salmonella typhimurium poultry marker strain to fresh produce extracts. Bioresour Technol 2003a;89:313-316. 
Nutt JD, Pillai SD, Woodward CL, et al. Use of a Salmonella typhimurium hilA fusion strain to assess effects of environmental fresh water sources on virulence gene expression. Water Res 2003b;37:3319-3326.

O'Bryan CA, Crandall PG, Ricke SC, et al. Impact of irradiation on the safety and quality of poultry and meat products: a review. Crit Rev Food Sci Nutr 2008;48:442-457.

Park EJ, Alexander E, Taylor GA, et al. 2008. Fate of foodborne pathogens on green onions and tomatoes by electrolysed water. Lett Appl Microbiol 2008;46:519-525.

Parnella T, Harrisa L, and Suslowb T. Reducing Salmonella on cantaloupes and honeydew melons using wash practices applicable to postharvest handling, foodservice, and consumer preparation. Int J Food Microbiol 2005;99:59-70.

Patterson M. Role of irradiation in a multiple hurdle approach to food safety. In Irradiation food safety and food quality. Loaharanu P and Thomas P (eds). Basel, Switzerland: Technomic Pub., 2001, pp. 71-79.

Pezzoli L, Elson R, Little C, et al. Packed with SalmonellaInvestigation of an international outbreak of Salmonella Senftenberg infection linked to contamination of prepacked basil in 2007. Foodborne Path Dis 2008;5:661-668.

Polo F, Figueras MJ, Inza I, et al. Relationship between presence of Salmonella and indicators of faecal pollution in aquatic habitats. Fed Euro Microbiol Soc Microbiol Lett 1998;160:253256.

Proctor ME, Hamacher M, Tortorello ML, et al. Multistate outbreak of Salmonella serovar Muenchen infections associated with alfalfa sprouts grown from seeds pretreated with calcium hypochlorite. J Clin Microbiol 2001;39:3461-3465.

Ray B. Impact of bacterial injury and repair in food microbiology: its past, present and future. J Food Prot 1986;49:651655.

Ricke SC. Perspectives on the use of organic acids and short chain fatty acids as antimicrobials. Poult Sci 2003;82:632-639.

Romling U, Gomelsky M, and Galperin MY. C-di-GMP: the dawning of a novel bacterial signalling system. Mol Microbiol 2005;57:629-639.

Saleha AA. Epidemiological study of the colonization of chickens with Campylobacter in broiler farms in Malaysia: possible risk and management factors. Int J Poult Sci 2004;3:129-134.

Santander J and Robeson J. Phage-resistance of Salmonella enterica serovar Enteritidis and pathogenesis in Caenorhabditis elegans is mediated by the lipopolysaccharide. J Biotech 2007;10. Available at http://www.ejbiotechnology.cl/content/ vol10/issue4/abstract/14/index.html.

Santo Domingo JW, Harmon S, and Bennett J. Survival of Salmonella species in river water. Curr Microbiol 2000;40:409-417.

Saroj SD, Hajare S, Shashidhar R, et al. Radiation processing for elimination of Salmonella typhimurium from inoculated seeds used for sprout making in India and effect of irradiation on germination of seeds. J Food Prot 2007;70:1961-1965.

Schirra M, D'hallewin G, Ben-Yehoshua S, et al. Host pathogen interactions modulated by heat treatment. Postharvest Biol Technol 2000;21:71-85.

Sewell AM and Farber JM. Foodborne outbreaks in Canada linked to produce. J Food Prot 2001;64:1863-1877.

Shi X, Namvar A, Kostrzynska M, et al. Persistence and growth of different Salmonella serovars on pre- and postharvest tomatoes. J Food Prot 2007;70:2725-2731.

Sivapalasingam S, Barrett E, Kimura A, et al. A multistate outbreak of Salmonella enterica Serotype Newport infection linked to mango consumption: impact of water-dip disinfestation technology. Clin Infect Dis 2003;37:1585-1590.
Sivapalasingam S, Friedman CR, Cohne L, et al. Fresh produce: a growing cause of outbreaks of foodborne illness in the United States, 1973 through 1997. J Food Prot 2004;67:23422353.

Solomon E, Yaron S, and Matthews K. Transmission of Escherichia coli O157:H7 from contaminated manure and irrigation water to lettuce plant tissue and its subsequent internalization. J Appl Environ Microbiol 2002;68:397-400.

Soto M, Chavez G, Baez M, et al. Internalization of Salmonella Typhimurium into mango pulp and prevention of fruit pulp contamination by chlorine and copper ions. Int J Environ Health Res 2007;17:453-459.

Sperber W. Determining critical control points. In: HACCP Principles and Applications. Pierson M, Corlett D (eds.). New York: Van Nostrand Reinhold, 1992, pp. 39-49.

Steele $\mathrm{M}$ and Odumeru J. Irrigation water as source of foodborne pathogens on fruit and vegetables. J Food Prot 2004;67:28392849.

Taormina PJ, Beuchat LR, and Slutsher L. Infections associated with eating seed sprouts: an international concern. Emerg Infect Dis 1999;5:626-634.

Tauxe R, Kruse H, Hedberg C, et al. Microbial hazards and emerging issues associated with produce, a preliminary report to the national advisory committee on microbiologic criteria for foods. J Food Prot 1997;60:1400-1408.

Thomas C and O'Beirne D. Evaluation of the impact of shortterm temperature abuse on the microbiology and shelf life of a model ready-to-use vegetable combination product. Int J Food Microbiol 2000;59:47-57.

Thomas J, Palumbo M, Farrar J, et al. Industry practices and compliance with U.S. Food and Drug Administration guidelines among California sprout firms. J Food Prot 2003;66:12531259.

Tournas VH. Spoilage of vegetable crops by bacteria and fungi and related health hazards. Crit Rev Microbiol 2005;31:3344.

Uhlich GA, Sinclair JR, Warren NG, et al. Characterization of Shiga toxin-producing Escherichia coli isolates associated with two multistate food-borne outbreaks that occurred in 2006. Appl Environ Microbiol 2008;74:1268-1272.

Ukuku D and Fett W. Relationship of cell surface charge and hydrophobicity to strength of attachment of bacteria to cantaloupe rind. J Food Prot 2002;65:1093-1099.

Ukuku D and Sapers G. Effect of time before storage and storage temperature on survival of Salmonella inoculated on fresh-cut melons. Food Microbiol 2007;24:288-295.

[USDA-ERS] United States Department of Agriculture-Economic Research Service. U.S. lettuce statistics. Available at http:// usda.mannlib.cornell.edu/data-sets/crops/lettuce/. Ithaca, NY: USDA Economics and Statistics System, Albert R. Mann Library, Cornell University, 2005.

[USDA-ERS] United States Department of Agriculture-Economic Research Service. Foodborne illness cost calculator for Salmonella. Available at http://www.ers.usda.gov/Data/ FoodborneIllness/salm_Intro.asp. Accessed August 13, 2008. Washington, DC: USDA-ERS, 2007.

[USDA-ERS] United States Department of Agriculture-Economic Research Service. What share of U.S. consumed food is imported? Amber Waves. February 2008. Available at http:// www.ers.usda.gov/AmberWaves/February08/DataFeature/. Washington, DC: USDA-ERS, 2008.

[USDA, FDA/CFSAN] U.S. Department of Agriculture; U.S. Food and Drug Administration, Center for Food Safety and Applied Nutrition. Guidance for industry guide to minimize 
microbial food safety hazards for fresh fruits and vegetables. Available at http://www.foodsafety.gov/ dms/prodguid .html\#ii. 1998.

Vargas M, Pastor C, Chiralt A, et al. Recent advances in edible coatings for fresh and minimally processed fruits. Crit Rev Food Sci Nutr 2008;48:496-511.

Van Beneden C, Keene W, Strang R, et al. Multinational outbreak of Salmonella enterica serotype Newport infections due to contaminated alfalfa sprouts. JAMA 1999;251:158-162.

Van Immerseel F, Russell JB, Flythe MD, et al. The use of organic acids to combat Salmonella in poultry: a mechanistic explanation of the efficacy. Avian Pathol 2006;35:182-188.

Voetsch AC, Van Gilder T, Angulo F, et al. FoodNet estimate of the burden of illness caused by nontyphoidal Salmonella infections in the United States. Clin Infect Dis 2004;38:S127134.

Winthrop KL, Palumbo MS, Farrar JA, et al. Alfalfa sprouts and Salmonella Kottbus infection: a multistate outbreak following inadequate seed disinfection with heat and chlorine. J Food Prot 2003;66:13-17.

Wolf ID, Schwartau CM, Thompson DR, et al. The $\mathrm{pH}$ of 107 varieties of Minnesota-grown tomatoes. J Food Sci 1979;44: 1008-1010.
Xiong R, Xie G, and Edmondson A. The fate of Salmonella enteritidis PT4 in home-made mayonnaise prepared with citric acid. Lett Appl Microbiol 1999;28:36-40.

Zagory D. Effects of post-processing handling and packaging on microbial populations. Postharvest Biol Technol 1999;15:313321.

Zhuang RY, Beuchat LR, and Angulo FJ. Fate of Salmonella Montevideo on and in raw tomatoes as affected by temperature and treatment with chlorine. Appl Environ Microbiol 1995;61:2127-2131.

Zogaj X, Nimtz M, Rohde M, et al. The multicellular morphotypes of Salmonella typhimurium and Escherichia coli produce cellulose as the second component of the extracellular matrix. Mol Microbiol 2001;39:1452-1463.

Address correspondence to: Irene B. Hanning, B.S., Ph.D.

Department of Food Science University of Arkansas 2650 Young Ave. Fayetteville, AR 72704

E-mail: ihanning@uark.edu 